\title{
RESPONS PETANI IKAN TERHADAP KELEMBAGAAN PRODUKSI DENGAN POLA KEMITRAAN
}

\author{
Tajerin " dan Endi Setiadi Kartamihardja*
}

\begin{abstract}
ABSTRAK
Respons petani ikan Jawa Barat terhadap kelembagaan produksi dengan pola kemitraan telah dikaji mulai bulan Mei 1995 sampai Februari 1996. Penarikan sampel dilakukan secara bertahap dalam penentuan lokasi penelitian dan dilanjutkan secara acak proporsional dalam pengambilan responden. Data kualitatif dianalisis secara deskriptif sedangkan data kuatitatif dianalisis menggunakan uji Chi-Square dan uji kebebasan. Hasil penelitian menunjukkan bahwa $67 \%$ responden tertarik dan berminat mendukung penerapan kelembagaan produksi dengan pola kemitraan. Atribut yang perlu ditonjolkan dalam program pengembangan dan strategi penerapan pada tahap selanjutnya adalah saling menguntungkan, independensi, kesetaraan, kesamaan komitmen, saling membutuhkan, dan komunikasi timbal balik. Keenam atribut tersebut mendapat respons positif lebih dari $60 \%$ dan berpengaruh nyata terhadap tingkat keinginan mendukung penerapan pola kemitraan ini. Sedangkan atribut kelembagaan yang masih perlu disempurnakan adalah keterpaduan, karena $43 \%$ responden memberikan respons ragu-ragu dan berpengaruh nyata $(P<0,10)$ terhadap tingkat keinginan mendukung penerapannya.
\end{abstract}

ABSTRACT: Fish farmer response to production institution with partnership pattern. By: Tajerin and Endi Setiadi Kartamihardja

A study on West Java fish farmer response to production institution with partnership pattern was conducted from May 1995 to February 1996. Sampling used using cluster and purposive methods. Data were decriptively and statistically analyzed using Chi-square and Dependency Tests. The results showed that $67 \%$ of the respondents supported the application of production institution with partnership pattern. Attributes which should be strengthened in the development and application of production institution were benefit mutualization, independency, equalization, same commitment, reciprocal need and communication. All of these atributes were supported positively by more than $60 \%$ of the respondents. Responses of the respondents on these six attributes affected significantly on the supporting level to the application on production institution. The integration atribute should be improved because $43 \%$ of the respondents were significanly hesitate to supported the application production institution $(P<0,10)$.

KEYWORDS: $\quad$ fish farmer respons, atribute, concept, institution, partnership

\section{PENDAHULUAN}

Setiap masyarakat hidup dalam bentuk dan dikuasai oleh lembaga-lembaga tertentu. Lembaga atau kelembagaan adalah organisasi atau kaidahkaidah, baik formal maupun non-formal yang mengatur perilaku atau tindakan anggota masyarakat tertentu baik dalam kegiatan rutin sehari-hari maupun dalam usahanya untuk mencapai tujuan tertentu (Mubyarto, 1982).

Perkembangan usaha tani di Indonesia dewasa ini ditandai munculnya bentuk kelembagaan produksi menggunakan pola PIR (Perusahaan Inti Rakyat) pada berbagai komoditas pertanian. Pemikiran ini merupakan jawaban atas lingkaran masalah yang sulit dipecahkan untuk mengatasi petani kecil melalui pembangunan yang terpadu

Penerapan konsep kelembagaan dalam bidang perikanan belum banyak dilakukan. Padahal kehadiran kehadiran kelembagaan ini sangat diperlukan. Khusus pada usaha budi daya ikan air tawar, penerapan konsep kelembagaan ini diupayakan melalui Pola Usaha Kemitraan (PUK) yang memiliki kekhasan dan berbeda dengan pola PIR yang umum dimiliki oleh kelembagaan produksi pada komoditas pertanian lainnya, karena budi daya ikan air tawar memiliki karakteristik sistem usaha tani yang berbeda dengan komoditas pertanian lainnya. Usaha budi daya ikan air tawar memiliki skala kecil dan berada secara sporadis di banyak lokasi, sedangkan pada komoditas pertanian lainnya cenderung memiliki skala usaha yang relatif lebih besar dan cenderung berada pada suatu wilayah hamparan usaha tani.

Konsep kelembagaan produksi dengan menggunakan pola kemitraan bagi dunia usaha budi daya ikan air tawar sampai saat ini masih merupakan suatu penemuan ide baru (inovasi) dan sebagai tahap awal 
dari proses pengembangan sistem kelembagaan produksi yang pernah ada. Mengingat peranan kelembagaan produksi tersebut pada usaha budi daya perikanan air tawar sangat diperlukan, maka pada tahap berikutnya perlu dilakukan pengujian keterkaitan kelembagaan tersebut dengan respons petani ikan terhadap beberapa atribut kemitraan. Untuk itu perlu disusun konsep kelembagaan produksi sebagai suatu produk baru yang akan diperkenalkan. Konsep produk adalah ide produk yang dinyatakan dalam terminologi yang berarti bagi konsumen yang dalam hal ini adalah petani (Kotler, 1993).

Konsep produk baru tersebut disebarkan kepada para petani sebagai sasaran. Bila penilaian positif dari petani terhadap penerapan konsep pola kemitraan dalam kelembagaan produksi sebagai suatu produk baru lebih dari $40 \%$, maka dapat dianggap bahwa produk baru tersebut memiliki daya tarik (Kotler, 1993). Bila kondisi ini tercapai, maka proses pengembangan konsep kelembagaan produksi menggunakan pola kemitraan dapat dilanjutkan pada tahap penyusunan strategi penerapan dan analisis serta penyempurnaan terhadap beberapa atribut kelembagaan tersebut yang banyak mendapat respons ragu-ragu atau tidak setuju dari petani. Konsep kelembagaan produksi dengan menggunakan pola kemitraan dalam usaha budi daya ikan air tawar secara simbolis adalah sebagai berikut.

Kelembagaan produksi dalam usaha budi daya ikan air tawar melibatkan petani-petani pada unit pembenihan, pendederan, dan pembesaran, bahkan bila mungkin melibatkan para pengusaha besar baik yang bergerak di bidang perikanan maupun bukan. Kelembagaan tersebut mengikuti pola kemitraan antara pihak-pihak yang terlibat langsung di atas secara fungsional dan bukan struktural. Kemitraan dalam kelembagaan produksi tersebut memiliki beberapa alternatif, seperti: Model Kelembagaan Gabungan Kelompok Tani (Gapoktan), Model Kelembagaan Kolaborasi (Bapak Angkat), Model Kelembagaan PIR, atau model kelembagaan produksi lainnya. Model-model kelembagaan tersebut dalam konsep awalnya ini belum ditentukan pemilihannya. Namun pada prinsipnya, model-model alternatif tersebut merupakan model dari kelembagaan yang mampu mendukung dan mengakomodasikan kebutuhan dalam proses produksi dan pemasaran hasil. Dalam model-model tersebut, pola hubungan kemitraan antara pihak-pihak yang terkait langsung di dalam kelembagaan produksi di atas harus memenuhi beberapa kriteria yang tercermin dalam minimal tujuh buah atribut yang menjadi syarat dari kemitraannya. Ketujuh atribut tersebut adalah: (1) kesetaraan; (2) independensi; (3) keterpaduan; (4) kesamaan komitmen (disiplin); (5) komunikasi timbal balik; (6) saling membutuhkan, dan (7) saling menguntungkan (Frinkle \& Gable, 1987; Hernanto, 1989; Higgins, 1985; Sinaga, 1985; Mubyarto, 1994).

Penerapan konsep kelembagaan produksi menggunakan pola kemitraan pada usaha budi daya perikanan air tawar, dari sudut sosiologis dipandang sebagai suatu stimulus dan memberi konsekuensi pada perubahan perilaku petani ikan sebagai individu dalam mengelola usaha taninya. Setiap perubahan perilaku petani ikan yang timbul dari adanya kelembagaan ini, pada pokoknya merupakan respons petani ikan tersebut terhadap kelembagaan produksi.

Pengetahuan mengenai besarnya derajat respons petani ikan terhadap kelembagaan produksi di atas dapat berguna sebagai indikasi bagi keberhasilan penerapan konsep kelembagaan produksi tersebut. Dengan adanya tambahan manfaat yang akan diterima petani dari penerapan kelembagaan produksi dengan pola kemitraan, maka petani akan tertarik dan berminat untuk mendukungnya dan secara konsisten terlibat aktif dalam menerapkannya. Oleh karena itu, analisis mengenai respons petani ikan terhadap kelembagaan produksi tersebut merupakan bagian yang sangat penting dalam rangka pengembangan usaha budi daya perikanan air tawar pada masa mendatang

Kegiatan penelitian ini diharapkan akan memperoleh data dan informasi mengenai konsep dasar kemitraan dalam kelembagaan produksi melalui perolehan data dan informasi mengenai (i) minat mendukung terhadap kelembagaan produksi menggunakan pola kemitraan, dan (ii) besarnya derajat respons petani ikan terhadap kelembagaan produksi.

\section{BAHAN DAN METODELOGI PENELITIAN}

\section{Pengumpulan Data}

Daerah Jawa Barat dipilih sebagai lokasi penelitian dengan pertimbangan bahwa daerah ini memiliki kondisi budi daya perikanan air tawar yang relatif intensif dan pesat perkembangannya. Selanjutnya pemilihan populasi sampel, subpopulasi, atau subwilayah penelitian dilakukan secara sengaja dan bertahap (purposive and cluster). Berdasarkan informasi dari Dinas Perikanan Tingkat I Jawa Barat diketahui bahwa Wilayah Perikanan Jawa Barat dapat digolongkan dalam tiga golongan, yaitu wilayah Selatan Jawa, Utara Jawa, dan Bagian Tengah. Dengan menggunakan metode pengambilan sampel 
di atas, dapat ditentukan beberapa lokasi pada masing-masing subwilayah berdasarkan kondisi fisiografisnya, yaitu Daerah Tingkat II Kabupaten Tasikmalaya, Daerah Tingkat II Kabupaten Subang, Daerah Tingkat II Kabupaten Bandung dan Sukabumi masing-masing mewakili subwilayah bagian selatan, utara, dan tengah Jawa Barat. Penentuan petani responden dari setiap lokasi yang mewakili subwilayah penelitian ditarik secara acak menggunakan metode estimasi proporsi (Nasir, 1983). Dengan cara ini diperoleh petani responden keseluruhan sebanyak 90 orang dengan rincian klasifikasi (menonjol) pembenih sebanyak 45 orang, pendeder sebanyak 27 orang, dan pembesar sebanyak 18 orang. Data primer diperoleh melalui metode wawancara menggunakan kuesioner dengan bentuk pertanyaan terbuka dan dilakukan secara persuasif.

\section{Analisis Data}

Penelitian ini merupakan studi deskriptif yang dilaksanakan dengan menggunakan metode survai. Data dan informasi berupa gambaran suatu tindakan sosial petani yang tidak diperoleh dengan cara melakukan pengukuran atau penghitungan dianalisis dengan pendekatan kualitatif, sedangkan pendekatan kuantitatif hanya dilakukan terhadap data dan informasi yang dikumpulkan melalui pengukuran atau penghitungan. Analisis data kualitatif dipilih dengan metode Lewis (1988) untuk mendeskripsikan pola dan sistem makna kebudayaan yang mendasari dan memberi pedoman terhadap tindakan sosial petani. Sedangkan analisis kuantitatif hanya digunakan untuk mengukur gejala sosial petani. Analisis kuantitatif terhadap minat mendukung kelembagaan produksi berdasarkan kelompok petani (pembenih, pendeder, dan pembesar) digunakan statistik nonparametrik dengan pendekatan model uji khi-kuadrat independensi k sampel (Siegel, 1992; Ericson \& Nosanchuk, 1983). Uji tersebut dilakukan dengan berdasarkan rumus

$$
X^{2}=\sum_{i=1 j=1}^{r k} \frac{O_{i j}-E_{i j}}{E_{i j}}
$$

dengan:

$\mathrm{O}_{i \mathrm{i}}=$ jumlah observasi untuk kasus-kasus yang dikategorikan dalam baris ke-i pada kolom kej,

$E_{i j}=$ banyaknya kasus yang diharapkan di bawah $\mathrm{H}_{0}$ untuk dikategorikan dalam baris ke-i pada kolom ke-j.

Untuk mengetahui keterkaitan antara respons terhadap kelembagaan produksi (setuju, ragu-ragu, dan tidak setuju) dengan minat mendukung terhadap kelembagaan produksi (positif, netral, dan negatif) digunakan uji kebebasan dua faktor dengan cara menentukan koefisien kontingensi $C$ dan membandingkannya dengan koefisien kontingensi maksimum yang dapat terjadi (Walpole, 1993). Uji tersebut dilakukan dengan berdasarkan rumus:

$C=\left[X^{2} /\left(X^{2}+n\right)\right]^{0.5} ;$ dengan nilai $C_{\text {maks }}=[(m-1) /$ $m]^{0.5}$

dengan:

$\mathrm{X}^{2}=$ nilai statistik chi-kuadrat dalam uji kebebasan dua faktor

$\mathrm{m}$ : adalah nilai minimum antara banyak baris dan banyak kolom.

Makin dekat nilai $\mathrm{C}$ dengan nilai $\mathrm{C}_{\text {maks }}$ maka makin besar derajat keterkaitan antara faktor yang diuji.

\section{HASIL DAN BAHASAN}

\section{Karakteristik Petani Responden}

Gambaran tentang karakteristik petani seperti: umur, tingkat pendidikan, jumlah, dan tanggungan anggota keluarga, serta status petani terhadap lahan garapannya akan sangat membantu untuk melihat sejauh mana aspek-aspek tersebut mampu mempengaruhi sikap petani dalam pengambilan keputusan (Saleh, 1985). Sedangkan sikap yang menumbuhkan motif petani terhadap suatu stimulus akan mempengaruhi bentuk respons petani (Mar'at, 1982).

Hasil penelitian menunjukkan bahwa umur petani responden bervariasi antara 26 sampai 65 tahun, dengan rata-rata umur 46 tahun yang tergolong dalam umur produktif. Petani responden terbanyak pada masing-masing kelompok yaitu pembenih $(39,1 \%)$ berada dalam kelompok umur $35-45$ tahun, pendeder $(37,8 \%)$ berada dalam kelompok umur 45 49 tahun, dan pembesar $(33,3 \%)$ berada dalam kelompok umur 45-49 tahun.

Dari hasil pengamatan, ternyata sebagian besar petani responden pada kelompok pembenih, pendeder, dan pembesar (masing-masing: $49,0 \%, 48,6 \%$, dan $33,3 \%$ ) berpendidikan rendah hanya tamat SD, dengan rata-rata lama pendidikan 6,8 tahun. Pendidikan, di samping dapat meningkatkan kemampuan berfikir dalam berusaha tani, juga dapat meningkatkan kemampuan dalam menangkap informasi dan pengadopsian teknologi terutama yang berkaitan dengan kegiatan usaha taninya.

Apabila dilihat dari jumlah dan komposisi anggota keluarganya, maka angka beban tanggungan keluarga dari ketiga kelompok petani (pembenih, pendeder, dan pembesar) masing-masing sebesar $59,6 \%, 70,3 \%$, dan $73,1 \%$ (jika usia kerja didefinisikan dari anggota keluarga petani responden yang berumur 15-54 tahun). Angka tersebut berarti bahwa dari 100 orang petani yang tergolong dalam usia kerja (15-54 tahun) 
terdapat masing-masing sebanyak 60, 70, dan 73 orang pada kelompok pembenih, pendeder, dan pembesar yang tidak produktif.

Atas dasar penggunaan lahan garapan sebagai sumber daya penting dalam kegiatan usaha budi daya ikan air tawar, menurut Soehardjo \& Patong (1973), petani dikelompokkan dalam petani pemilik. penyewa, penyakap (bagi hasil), atau kombinasi dari ketiganya. Dari hasil pengamatan, sebagian besar petani responden pada ketiga kelompok (pembenih, pendeder, dan pembesar) terdiri atas petani pemilik, masing-masing sebanyak $89,1 \%, 92,3 \%$, dan $72,3 \%$. Sedangkan petani penyewa dan penyakap hanya sebagian kecil saja. Petani penyewa hanya terdapat pada kelompok pembesar sebanyak $16,7 \%$, dan petani penyakap untuk kelompok petani pembenih, pendeder, dan pembesar masing-masing sebanyak $10,9 \%, 7,7 \%$, dan $11 \%$. Kecilnya proporsi petani penyewa dan penyakap di atas, kemungkinan berhubungan dengan harga atau sewa lahan yang relatif mahal. Kemungkinan lainnya adalah, pemilik lahan telah menarik kembali lahannya dari pihak penggarap dan memberikan kepada anggota keluarganya untuk diusahakan sendiri.

\section{Manfaat Kelembagaan Produksi Menggunakan Pola Kemitraan}

Kelembagaan produksi dalam usaha budi daya ikan air tawar yang menggunakan pola kemitraan, masih merupakan hal yang baru bagi petani ikan air tawar. Pada dasarnya, petani ikan telah mengenal bahkan pernah dan sedang melakukan aktivitas kegiatan produksi dengan menggunakan bentuk kelembagaan, seperti Kelompok Petani lkan, Paguyuban Pengusaha Ikan, Himpunan Pengusaha Perikanan Air Tawar (Hipikat). Dalam prakteknya, kelembagaankelembagaan tersebut kurang memperhatikan unsurunsur hubungan kemitraan antar petani anggota yang terlibat dalam masing-masing unit usaha pembenihan, pendederan, dan pembesaran karena seringkali terjadi hal-hal yang menyulitkan petani ikan. Hal-hal tersebut antara lain: (1) ketidakseimbangan produksi antara unit pembenih, unit pendeder, dan unit pembesar; (2) kesulitan mendapatkan benih ikan yang baik dengan jumlah yang memadai; (3) kesulitan mendapatkan bantuan modal bagi pembiayaan usaha dalam waktu segera; (4) ketidakpastian pemasaran hasil, baik harga jumlah dan lokasi pembeli; dan (5) praktek pembayaran terhadap penjualan ikan yang tidak tepat waktu yang seringkali menghambat proses produksi berikutnya.

Menurut Sinaga (1985) manfaat kelembagaan produksi pada pengelolaan usaha tani secara terintegrasi adalah: (a) peningkatan efisiensi usaha melalui pemanfaatan teknologi dan manajemen modern, (b) peningkatan mekanisme proses pemerataan pendapatan melalui kesempatan berusaha, dan (c) memecahkan kelemahan-kelemahan yang ada dalam dualisme ekonomi. Sedangkan menurut Ladcome (1982), melalui kelembagaan produksi ini dimungkinkan terjadi peningkatan kualitas usaha tani, di mana para petani diintegrasikan dalam kelompok-kelompok yang menyeluruh dalam satu sistem serta terlihat atau merupakan bagian program pengembangan komoditas. Perbaikan kualitas usaha tani melalui kelembagaan produksi ini diupayakan untuk memecahkan masalah usaha tani yang meliputi: (a) kurang rangsangan; (b) lemah tingkat teknologinya; (c) langkanya permodalan untuk pembiayaan usaha tani; (d) transformasi dan komunikasi; (e) kurangnya informasi; ( $f$ ) adanya kesenjangan penelitian terpakai untuk petani; $(\mathrm{g})$ luasnya usaha yang tidak menguntungkan; ( $h$ ) belum mantapnya sistem dan pelayanan penyuluhan, dan (i) aspek sosial, politik, ekonomi yang berkaitan dengan kebijaksanaan bagi petani

Dengan diajukannya suatu konsep kelembagaan produksi yang menggunakan pola kemitraan, petani ikan berharap kelembagaan yang baru ini akan memberikan manfaat bagi perbaikan kualitas pada aktivitas usahanya. Secara rinci harapan petani terhadap manfaat yang akan diperoleh kelembagaan produksi tersebut tertera pada Tabel 1.

Dari Tabel 1 diketahui bahwa manfaat yang sangat diharapkan oleh petani bila diterapkan sistem kelembagaan produksi yang menggunakan pola kemitraan adalah peningkatan mekanisme proses pemerataan pendapatan (30\%), peningkatan efisiensi usaha $(23 \%)$, serta peningkatan perolehan informasi pasar, kepastian pemasaran, dan pemantapan sistem dan pelayanan penyuluhan $(22 \%)$. Secara terpisah petani unit pembenihan dan pembesaran memiliki harapan yang relatif sama terhadap jenis manfaat yang sangat diharapkan, yaitu manfaat peningkatan mekanisme proses pemerataan pendapatan, peningkatan efisiensi usaha, peningkatan informasi dan kapastian pasar. Sedangkan petani unit pendederan memiliki harapan sangat besar, yang lebih ditonjolkan pada jenis manfaat peningkatan mekanisme proses pemerataan pendapatan.

Dari kondisi di atas, tampak bahwa terdapat dorongan yang sangat besar untuk memperoleh pemerataan pendapatan melalui kesempatan berusaha secara terorganisir dalam bentuk pola hubungan kemitraan antar petani yang bergerak di unit-unit usaha pembenihan. Sedangkan bagi petani unit-unit pembenihan dan pembesaran tampaknya tidak memiliki suatu dorongan tertentu yang secara khusus ditonjolkan dari kemungkinan diterapkan kelembagaan produksi yang menggunakan pola kemitraan tersebut. Hal ini menunjukkan adanya kepentingan yang lebih besar dari petani-petani unit 
Tabel 1. Beberapa harapan responden terhadap manfaat kelembagaan produksi menggunakan pola kemitraan pada usaha budi daya ikan air tawar

Table 1 Some expectations of respondents on the advantages of production institution with partnership pattern

\section{Manfaat yang diharapkan Expected advantages}

Kelompok Petani/Farmer Groups

\begin{tabular}{ccc}
\hline Pembenih & Pendeder Pembesar & $\begin{array}{c}\text { average } \\
\text { Fry Farmer }\end{array}$ Nursery Grow-out \\
$(\%)$ & farmer (\%) farmer (\%)
\end{tabular}

- Peningkatan efisiensi usaha melalui pemanfaatan teknologi usaha tani dan manajemen modern berwawasan bisnis dan lingkungan Improvement of effort efficiency through use of farming technology as well as business and environmentaly sound modern management

- Peningkatan mekanisme proses pemerataan pendapatan melalui kesempatan berusaha Improvement of process menchanism of income

- Peningkatan rangsangan berusaha tani melalui penyediaan sarana produksi dan permodalan untuk pembiayaan usahatani

Improvement of farming business stimulation through

supplying production faculties and in infrastructure capital farming expense

- Peningkatan perolehan informasi pasar dan kepastian pemasaran hasil dengan harga yang menggairahkan Improvement of acces to market information and ensure market of product with promising price

- Percepatan proses transformasi dan peningkatan intensitas komunikasi serta pemantapan sistem dan pelayanan penyuluhan Acceleration of transformation process and improvement of communication intencity as well as stabillization of extension system

\begin{tabular}{lllll}
\hline Jumlah (Total) & 100 & 100 & 100 & 100 \\
\hline
\end{tabular}

pembenihan dan pembesaran terhadap kehadiran kelembagaan produksi tersebut dibanding dengan petani-petani unit pendederan

\section{Analisis Respons Petani Ikan Terhadap Kelembagaan Produksi}

Berdasarkan pendekatan konsepsi penguat (Thoha, 1993) dijelaskan bahwa stimulus adalah sesuatu yang terjadi untuk mengubah perilaku seseorang. Suatu stimulus dapat berupa benda fisik ataupun berupa materi, yang dapat diukur dan diamati. Semua stimulus dapat dijumpai di dalam lingkungan manusia, dan setiap perubahan dalam perilaku pada individu manusia merupakan suatu respons. Dalam pendekatan konsepsi penguat, suatu respons terjadi karena adanya suatu stimulus.

Respons merupakan tanggapan yang diberikan seseorang terhadap stimulus yang dihadapinya. Suatu perkembangan atau perubahan dari suatu objek dapat menjadi stimulus bagi timbulnya respons pihak-pihak yang terlibat di dalamnya. Menurut Teori Stimulus-Respons Hosland, Mar'at (1982), proses timbulnya respons terjadi setelah individu memperhatikan, mengerti, memahami, dan menerima stimulus yang menghampirinya. Jika stimulus mendapat tanggapan (diterima) oleh individu, berarti adanya komunikasi dan perhatian dari individu 
Aktivitas individu untuk memperhatikan, mengerti, memahami, dan menerima stimulus menunjukkan telah berlangsungnya fungsi kognisi oleh individu dalam merespons suatu stimulus. Teori kognitif percaya bahwa perilaku seseorang itu disebabkan adanya suatu rangsangan (stimulus), yakni suatu objek fisik yang mempengaruhi seseorang dalam banyak cara. Menurut Teori Kognitif, semua perilaku itu tersusun secara teratur. Individu mengatur pengalamannya ke dalam aktivitas untuk mengetahui (cognition) yang kemudian memacaknya ke dalam susunan kognitifnya (cognitive structure). Susunan ini menentukan jawaban (respons) seseorang (Neisser, 1976).

Pengetahuan mengenai kognisi dipandang sangat penting dalam menjelaskan respons individu terhadap stimulus. Menurut Thoha (1993), terdapat beberapa fungsi dalam sistem kognitif antara lain: (1) memberikan pengertian pada kognitif baru, (2) menghasilkan emosi atau konsekuensi yang menunjukkan sikap, (3) membentuk sikap, dan (4) memberikan motivasi terhadap konsekuensi perilaku. Berdasarkan fungsi kognitif ini, ternyata respons seseorang berkaitan dengan sikapnya.

Secara sederhana, bentuk respons dapat dinyatakan sebagai sikap yang didasari oleh proses dalam diri dan individu guna memberi kesimpulan tentang nilai dari stimulus, apakah dianggap baik atau buruk, positif, atau negatif, menyenangkan atau tidak menyenangkan, disukai atau tidak disukai, yang kemudian mengkristal sebagai potensi reaksi terhadap stimulus Sax (1982) dalam Azwar (1988). Hal ini selaras dengan pendapat Mar'at (1982), bahwa respons itu muncul sebagai perwujudan dari sikap yang mengandung unsur penilaian dari reaksi efektif, menumbuhkan motif. Motif ini menghasilkan respons yang tampak berupa perilaku nyata, sedangkan reaksi afektifnya merupakan respons tersembunyi.

Studi mengenai respons masyarakat desa terhadap program-program pembangunan pertanian di pedesaan telah banyak dilakukan, dan diketahui bahwa derajat respons masyarakat desa terhadap suatu perkembangan atau perubahan bervariasi menurut arah, intensitas, dan konsistensi respons Sax (1982) dalam Azwar (1988), serta berkaitan dengan faktor-faktor seperti: Interaksi sosial dan kondisi sosial ekonomi (Mubyarto \& Kartodirdjo, 1988) serta pelapisan sosial (Zacharias, 1983; Husken, 1984; Hart, 1986; Husken \& White, 1989; White \& Wiradi, 1989; dan Tornquist, 1990).

Rumusan Mar'at (1982) menunjukkan bahwa respons memang merupakan reaksi terhadap stimulus. Namun bentuk respons itu sendiri dipengaruhi oleh sikap yang menumbuhkan motif perespons terhadap stimulus. Bentuk respons individu terhadap stimulus memiliki beberapa karakteristik yang menonjol. Menurut Sax (1982) dalam Azwar (1988). sedikitnya terdapat tiga karakteristik respons individu terhadap stimulus, yaitu: (1) arah respons, (2) intensitas respons, dan (3) konsistensi respons

Analisis respons individu terhadap suatu stimulus yang meliputi ketiga karakteristik respons di atas, digunakan juga dalam pengujian konsep kelembagaan produksi budi daya ikan air tawar yang menggunakan pola kemitraan. Pengujian konsep kelembagaan tersebut dilakukan melalui analisis daya tarik (minat mendukung) untuk melihat bagaimana arah respons petani ikan terhadap penerapan kelembagaan produksi tersebut, kemudian dikaitkan dengan respons petani ikan terhadap beberapa atribut pola kemitraan untuk mengetahui sejauh mana intensitas respons yang dimiliki petani ikan tersebut. Selanjutnya dilakukan pengujian tentang konsistensi respons petani ikan untuk mengetahui kesesuaian antara pernyataan yang diberikan dengan tingkah lakunya berkaitan dengan kelembagaan produksi tersebut dan ada dan tidaknya kebimbangan petani ikan tersebut dalam memberikan responsnya.

\section{Minat mendukung terhadap kelembagaan produksi}

Tingkat keinginan responden untuk mendukung penerapan kelembagaan produksi yang menggunakan pola kemitraan disajikan pada Tabel 2. Petani responden yang menilai positif (tertarik) terhadap penerapan pola kemitraan berjumlah $67 \%$, dan persentase terbesar dalam menilai positif ini diberikan oleh petani pembenih $(77 \%)$. Petani responden yang bersikap positif tersebut dapat dipastikan akan memberikan dukungan terhadap penerapan pola tersebut. Karena proporsi petani yang menilai positif tersebut lebih besar dari $40 \%$, maka dapat ditentukan bahwa kelembagaan produksi yang menggunakan pola kemitraan memiliki cukup daya tarik untuk diterapkan pada petani. Dengan demikian, tahapan selanjutnya dalam proses pengembangan kelembagaan produksi tersebut dapat dilakukan, termasuk penentuan model kelembagaan yang paling cocok (terpilih), sehingga dianggap layak secara teknis, ekonomis, sosial, dan penentuan strategi penerapannya

Petani responden yang menyatakan netral dalam arti tidak tertarik ataupun tidak menolak kehadiran kelembagaan produksi tersebut berjumlah $21 \%$. Petani responden yang bersikap netral tersebut sulit sekali untuk diramalkan apakah nantinya akan mendukung atau tidak mendukung. Keputusannya 
Tabel 2. Respons petani terhadap penerapan kelembagaan produksi dengan pola kemitraan dalam usaha budi daya ikan air tawar

Table 2. Respons of farmers to on the application of production institution with partnership pattern in aquaculture system

\begin{tabular}{|c|c|c|c|c|}
\hline \multirow{2}{*}{$\begin{array}{l}\text { Klasifikasi petani } \\
\text { Farmer clasification }\end{array}$} & \multicolumn{3}{|c|}{ Respons (Respons) } & \multirow[b]{2}{*}{$x^{2}$} \\
\hline & $\begin{array}{l}\text { Positif } \\
\text { Positive }\end{array}$ & $\begin{array}{l}\text { Netral } \\
\text { Neutral }\end{array}$ & $\begin{array}{l}\text { Negatif } \\
\text { Negative }\end{array}$ & \\
\hline Pembenihan $(F r y$ farmer $)(n=15)$ & $39(77)$ & $9(18)$ & $3(5)$ & $3,80^{\text {ns }}$ \\
\hline Pendederan (Nursery farmer) $(n=27)$ & $16(60)$ & $6(23)$ & $5(17)$ & \\
\hline Pembesaran (Grow out) $(n=12)$ & $8(65)$ & $3(22)$ & $1(13)$ & \\
\hline Jumlah (Amount) & $63(67)$ & $18(21)$ & $9(12)$ & \\
\hline
\end{tabular}

akan sangat tergantung pada kelihaian usaha dalam strategi introduksi dan adopsi kelembagaan tersebut.

Bila ditelaah dari kelompok petani responden, ternyata penilaian terhadap kelembagaan produksi yang menggunakan pola kemitraan antara kelompok pembenih, kelompok pendeder, dan kelompok pembesar secara statistik menunjukkan perbedaan yang tidak nyata $(P>0,10)$. Meskipun persentase yang ada menunjukkan bahwa kelompok pembenih lebih tertarik dibanding kelompok pembesar dan kelompok pendeder, atau kelompok pembesar lebih tertarik daripada kelompok pendeder. Dengan demikian faktor perbedaan kelompok tersebut tidak berpengaruh nyata terhadap cara petani menilai daya tarik penerapan kelembagaan ini.

\section{Respons terhadap kelembagaan produksi}

Respons petani ikan terhadap kelembagaan produksi yang menggunakan pola kemitraan, pada penelitian ini hanya ditujukan pada pengujian respons petani ikan terhadap beberapa atribut kemitraan yang terdapat dalam konsep kelembagaan produksi di atas.

Respons petani ikan terhadap beberapa atribut yang digunakan dalam kelembagaan produksi disajikan pada Tabel 3. Dari Tabel 3 diketahui bahwa petani responden memberikan respons setuju yang tinggi pada atribut saling menguntungkan, atribut independensi, atribut kesetaraan, atribut kesamaan komitmen, atribut saling membutuhkan, dan atribut hubungan resiprokal. Atribut yang tergolong sangat menonjol dari keenam atribut tersebut adalah atribut saling menguntungkan dan atribut independensi. Kedua atribut tersebut memperoleh respons setuju (positif) yang sangat tinggi masing-masing sebanyak $87 \%$ dan $89 \%$, sedangkan keempat atribut lainnya memperoleh respons setuju (positif) berkisar antara $58 \%$ sampai $77 \%$.
Respons terhadap atribut saling menguntungkan dan atribut independensi yang sangat menonjol di atas, mencerminkan bahwa konsep awal dari kelembagaan produksi yang menggunakan pola kemitraan harus lebih menonjolkan kedua atribut tersebut dalam tahap pengembangannya. $\mathrm{Hal}$ ini menimbulkan pengertian bahwa konsep kelembagaan produksi tersebut seharusnya harus lebih ditekankan pada bagaimana mekanisme pelaksanaan model kelembagaan terpilih, yang mampu mengakomodasikan petani-petani kecil agar berpeluang untuk mempunyai posisi tawar-menawar (bargaining position) yang kuat terhadap petanipetani atau pengusaha besar, sehingga terwujud bentuk hubungan timbal balik yang mencerminkan kondisi saling menguntungkan antara petani yang memiliki akses produksi dan pasar yang lemah dan yang kuat dalam hubungan mitra kerja. Selain itu, hubungan mitra kerja tersebut bukan mengarah pada persaingan yang tidak sehat, akan tetapi lebih merupakan jalinan yang harus membawa semua pihak menuju pengembangan pemberdayaan, sehingga independensi masing-masing pihak dapat tetap dihargai yang pada gilirannya akan tercipta kemandirian di antara pihak-pihak yang bermitra

Di samping kedua atribut di atas, terdapat pula empat atribut lainnya yang juga harus ditonjolkan dalam tahap pengembangan konsep kelembagaan produksi, yaitu atribut-atribut kesetaraan, kesamaan komitmen, saling membutuhkan, dan hubungan komunikasi timbal balik. Keempat atribut ini mempunyai pengertian sebagai berikut:

(1) Atribut kesetaraan mencerminkan adanya kesetaraan posisi yang dimunculkan oleh pemahaman dan kesadaran akan peran serta yang harus dimainkan dengan baik oleh masing-masing pihak yang bermitra dalam kelembagaan produksi tersebut. 
Tabel 3. Respons petani ikan terhadap kelembagaan produksi pada usaha budi daya ikan air tawar berdasarkan tujuh atribut kemitraan $(n=90)$

Table 3. Respons of fish farmers on production institution in aquaculture system based on seven partnership atributes $(n=90)$

\begin{tabular}{|c|c|c|c|c|}
\hline \multirow{2}{*}{$\begin{array}{l}\text { Jenis atribut } \\
\text { Kind of attributes }\end{array}$} & \multicolumn{4}{|c|}{ Respons petani ikan (Fish farmer Respons $(n=90)$ ) } \\
\hline & $\begin{array}{c}\text { Setuju } \\
\text { Agree (\%) }\end{array}$ & $\begin{array}{l}\text { 'Ragu-ragu } \\
\text { Hesitant (\%) }\end{array}$ & $\begin{array}{l}\text { Tidak setuju } \\
\text { Disagree (\%) }\end{array}$ & $\begin{array}{l}\text { Jumlah } \\
\text { Total (\%) }\end{array}$ \\
\hline $\begin{array}{l}\text { Kesetaraan } \\
\text { Equalization }\end{array}$ & 77 & 22 & 1 & 100 \\
\hline $\begin{array}{l}\text { Independensi } \\
\text { Independency } \\
\text { Keterpaduan }\end{array}$ & 87 & 10 & 3 & 100 \\
\hline $\begin{array}{l}\text { Keterpaduan } \\
\text { Integration } \\
\text { Kesamaan Komitmen (Disiplin) }\end{array}$ & 45 & 43 & 12 & 100 \\
\hline Same commitment (Discipline) & 68 & 26 & 6 & 100 \\
\hline $\begin{array}{l}\text { Komunikasi timbal balik } \\
\text { Reciprocal communication }\end{array}$ & 58 & 34 & 8 & 100 \\
\hline $\begin{array}{l}\text { Saling membutuhkan } \\
\text { Reciprocal need }\end{array}$ & 61 & 33 & 6 & 100 \\
\hline $\begin{array}{l}\text { Saling menguntungkan } \\
\text { Mutualism }\end{array}$ & 89 & 7 & 4 & 100 \\
\hline Rata-rata (Average) & 68 & 26 & 6 & 100 \\
\hline
\end{tabular}

(2) Atribut kesamaan komitmen mencerminkan adanya kesamaan sikap yang diwarnai iktikad baik yang secara konsisten akan tetap menjadi pegangan dan cerminan kedisiplinan masingmasing pihak dalam melakukan kemitraan.

(3) Atribut saling membutuhkan menunjukkan bentuk hubungan yang mencerminkan adanya kepentingan terhadap kebutuhan bersama antara pihak yang bermitra

(4) Atribut hubungan komunikasi timbal balik menunjukkan bentuk hubungan yang mencerminkan pola komunikasi antara pihak-pihak yang menjalin hubungan kemitraan untuk melakukan suatu proses pertukaran kejadian-kejadian dan pendapat-pendapat

Walaupun demikian, karena kelembagaan produksi tersebut memiliki kelemahan pada atribut lainnya, dan mungkin adanya motif berafiliasi serta loyalitas yang tinggi terhadap tradisi berkelompok secara lokal (non cosmopolit), maka terdapat pula petani responden yang bersikap ragu-ragu bahkan tidak setuju terhadap kehadiran kelembagaan produksi yang menggunakan pola kemitraan

Petani responden yang memberikan respons ragu-ragu yang tinggi pada atribut keterpaduan mencapai 43\%. Hal ini menunjukkan adanya kelemahan dari konsep kelembagaan produksi yang harus disempurnakan. Untuk menghindari kemungkinan kegagalan kelembagaan produksi yang menggunakan pola kemitraan, perlu upaya mendapatkan suatu model kelembagaan produksi yang cocok dengan kondisi usaha budi daya ikan air tawar yang sebagian besar skala usahanya kecil dan berada terpencar secara sporadis di banyak lokasi yang secara relatif tidak dalam satuan hamparan usaha tani.

\section{Konsistensi respons petani ikan}

Dalam kerangka penguraian suatu respons individu, selain harus dijelaskan mengenai arah respons dan intensitas respons, juga perlu dijelaskan konsistensi respons individu. Melalui penelaahan konsistensi respons dapat diuji apakah terdapat kesesuaian antara pernyataan yang dikemukakan oleh subyek dengan tingkah lakunya terhadap suatu stimulus. Selain itu, dari konsistensi respons ini akan dapat ditunjukkan ada atau tidaknya kebimbangan individu dalam memberikan suatu respons (Sax. 1982 dalam Azwar 1988). Konsistensi respons tersebut dipandang penting, karena pada tahap penerapan dapat menjadi faktor yang menentukan keberhasilan dari suatu kelembagaan produksi (Sarjana et al., 1994). Pernyataan subjek (individu) dalam hal ini adalah: (1) minat untuk mendukung penerapan kelembagaan produksi yang 
Tabel 4. Hasil uji kebebasan antara respons terhadap atribut kelembagaan produksi dengan tingkat keinginan mendukung penerapan kelembagaan produksi

Table 4. Test result on the dependency between respons on attributes of production institution and level of supporting intent of their application

\begin{tabular}{|c|c|c|c|}
\hline Parameter (Parameters) & $x^{2}$ & c & $\mathrm{C} / \mathrm{C}_{\text {maks }}(\%)$ \\
\hline Kesetaraan (Equalization) & 8.251 & 0.29 & 41.01 \\
\hline Independensi (Independency) & 11.364 & 0.335 & 47.38 \\
\hline Keterpaduan (Integration) & 4.681 & 0.222 & 27.19 \\
\hline $\begin{array}{l}\text { Kesamaan Komitmen (Disiplin) } \\
\text { Same commitment (Discipline) }\end{array}$ & 6.821 & 0.265 & 37.48 \\
\hline $\begin{array}{l}\text { Komunikasi timbal balik } \\
\text { Reciprocal communication }\end{array}$ & 5.363 & 0.237 & 33.52 \\
\hline Saling membutuhkan (Reciprocal need) & $6,425^{\star \star}$ & 0.258 & 36.49 \\
\hline Saling menguntungkan Mutualism & $13,822^{\star * *}$ & 0.365 & 51.62 \\
\hline
\end{tabular}

mencerminkan daya tarik kelembagaan tersebut, dan (2) respons terhadap kelembagaan produksi yang dalam hal ini ditinjau dari atribut-atribut yang digunakan dalam kelembagaan tersebut.

Hasil pengujian konsistensi respons disajikan pada Tabel 4. Dari Tabel ini diketahui bahwa terdapat hubungan yang nyata antara tingkat penilaian petani terhadap daya tarik kelembagaan produksi yang menggunakan pola kemitraan dengan respons petani ikan terhadap atribut hubungan resiprokal, atribut kesetaraan, atribut independensi, atribut kesamaan komitmen, atribut saling membutuhkan, dan atribut saling menguntungkan. Dengan demikian dapat diketahui pula bahwa tidak terdapat kebimbangan petani dalam memberikan respons terhadap kelembagaan produksi yang menggunakan atributatribut tersebut dalam pola hubungan kemitraannya.

Hubungan yang nyata dari keenam atribut di atas, ternyata terjadi pada taraf nyata yang berbeda-beda. Hubungan yang nyata $(P<0,01)$ terdapat pada atribut saling menguntungkan dan atribut independensi. Hal ini menunjukkan bahwa kedua atribut tersebut akan sangat mempengaruhi petani ikan untuk memberi dukungan dan berperan serta dalam kelembagaan produksi tersebut. Hal ini dengan demikian terbukti sangat relevan dengan pernyataan sebelumnya bahwa kedua atribut tersebut harus lebih ditonjolkan dalam tahap pengembangan konsep kelembagaan tersebut. Hubungan yang nyata $(P<0,05)$ terdapat pada atribut kesetaraan, atribut kesamaan komitmen, dan atribut saling membutuhkan. Hal ini menunjukkan bahwa ketiga atribut terbukti berpengaruh pula terhadap keinginan petani untuk memberi dukungan atau berperan serta dalam kelembagaan produksi, meskipun pengaruhnya tidak sekuat pada atribut saling menguntungkan dan atribut independensi Dengan demikian diketahui bahwa tidak terdapat kebimbangan petani memberikan respons terhadap ketiga atribut tersebut, dan terbukti pula bahwa di samping atribut saling menguntungkan dan atribut independensi, ketiga atribut tersebut perlu pula ditonjolkan sebagai atribut penting dalam kelembagaan produksi.

Hubungan yang tergolong kurang erat namun masih cukup nyata $(P<0,10)$ terdapat pada atribut hubungan komunikasi timbal balik dan atribut keterpaduan. Namun bila dikaitkan dengan data pada Tabel 3, hubungan yang terdapat pada kedua atribut tersebut menunjukkan kondisi yang cenderung berbeda. Hubungan antara respons terhadap atribut hubungan komunikasi timbal balik dan tingkat daya tarik kelembagaan lebih cenderung mengarah pada hubungan dalam menilai positif antara respons atribut hubungan komunikasi timbal balik dan penilaian daya tarik kelembagaan. Sedangkan hubungan yang terjadi pada atribut keterpaduan adalah cenderung menunjukkan hubungan dalam menilai positif namun diwarnai oleh keragu-raguan yang cukup tinggi $(43 \%)$. Dengan demikian, terbukti bahwa atribut hubungan resiprokal masih perlu ditonjolkan dalam pengembangan konsep kelembagaan produksi yang menggunakan pola kemitraan, sedangkan atribut keterpaduan justru harus mendapatkan perhatian untuk disempurnakan

\section{KESIMPULAN}

1. Kelembagaan produksi dalam usaha budi daya ikan air tawar yang menggunakan pola hubungan fungsional kemitraan mendapat respons positif (setuju) dari sebagian besar petani ikan (70\%), 
dengan alasan bahwa kelembagaan tersebut akan memberikan manfaat yang sangat diharapkan berupa: (a) peningkatan mekanisme proses pemerataan pendapatan melalui kesempatan berusaha, (b) peningkatan efisiensi usaha melalui pemanfaatan teknologi usaha tani dan manajemen modern berwawasan bisnis dan lingkungan, dan (c) peningkatan perolehan informasi pasar dan kepastian pemasaran hasil dengan tingkat harga yang menggairahkan.

2. Faktor perbedaan kelompok petani (kelompok pembenih, kelompok pendeder, dan kelompok pembesar) tidak memberikan pengaruh yang nyata terhadap minat petani untuk mendukung penerapan kelembagaan produksi yang menggunakan pola kemitraan. Kelembagaan produksi tersebut memiliki daya tarik yang tinggi untuk diterapkan karena mendapatkan respons positif sebesar $67 \%$

3. Atribut yang perlu ditonjolkan dalam pengembangan konsep dan penerapan kelembagaan produksi yang menggunakan pola kemitraan adalah atribut saling menguntungkan, atribut independensi, atribut kesetaraan, atribut kesamaan komitmen, atribut saling membutuhkan, dan atribut hubungan komunikasi timbal balik. Sedangkan atribut kelembagaan yang perlu dilakukan penyempurnaan adalah atribut keterpaduan yang banyak mendapatkan tanggapan ragu-ragu serta mempengaruhi tingkat penilaian petani terhadap daya tarik penerapan kelembagaan produksi menggunakan pola kemitraan.

\section{SARAN}

Pada tahap pengembangan konsep dan rencana introduksi dan adopsi kelembagaan produksi yang menggunakan pola kemitraan, perlu mempertimbangkan:

1. Proporsi yang tinggi pada atribut saling menguntungkan dan atribut independensi sebagai prinsip-prinsip hubungan fungsional kemitraan, mengingat kedua atribut mendapat respons positif sangat menonjol (masing-masing $89 \%$ dan $87 \%$ ).

2. Penentuan model kelembagaan produksi pada usaha budi daya ikan air tawar yang mampu menjawab permasalahan keterpaduan areal usaha yang terpencar secara sporadis di banyak lokasi dengan luasan yang relatif kecil, mengingat atribut keterpaduan mendapat respons ragu-ragu yang cukup tinggi (43\%).

\section{DAFTAR PUSTAKA}

Ericson, B.H. and T.A. Nosanchuk. 1983. Memahami Data. Lembaga Penelitian dan Penerangan Ekonomi dan Sosial (LP3ES). Jakarta. p. 299-319.
Frinkle J. and R. Gable. 1987. Political Development and Social Change. New York. John Wiley \& Sons. p.93135

Hart, G. P. 1986. Power, Labor and Livelihood. University of California Press. Berkeley. p.121-134

Hernanto, F. 1989. IImu Usaha Tani. Penebar Swadaya. 'Jakarta. p. 97-103

Husken, F. 1984. Capitalism and Agrarian Differentiation in a Javanese Village, dalam Hart et.al., eds., Agrarian Transformations, Local Processes and The State in the South-East Asia, Berkeley and Los Angeles. University of California Press. p. 127-188

Husken, F. and White, B. 1989. Java: Social Differentiation, Food Production and Agriculture Control, dalam Hart et. al., eds., Agrarian Transformations, Local Processes and the State in the South-East Asia. Berkeley and Los Angeles. California Press. p 235-265

Higgins, B. 1985. Economic Development: Principles. Problems, dan Policies. London. Constable and Co. p. 411-435.

Kotler, P. 1993. Manajemen Pemasaran: Analisis, Perencanaan, Implementasi, dan Pengendalian. Lembaga Penerbit Fakultas Ekonomi, Universitas Indonesia. Jakarta. p. 460-469.

Ladcome, L.A. 1982. Dialog with Asian rural man. A Workshop Report. Universitas Indonesia. Jakarta. 27 pp

Lewis, O. 1988. Kisah Lima Keluarga. Telaah-telaah kasus orang Meksiko dalam kebudayaan kemiskinan. Yayasan Obor Indonesia, Jakarta. p. 70-85

Mar'at. 1982. Sikap Manusia, Perubahan serta Pengukurannya. Ghalia Indonesia. Jakarta. p 36-54.

Mubyarto. 1982. Pengantar Ekonomi Pertanian. Lembaga Penelitian, Pendidikan dan Penerangan Ekonomi dan Sosial (LP3ES). Jakarta. p. 44-50.

Mubyarto. 1994. Sistem dan Moral Ekonomi Indonesia Lembaga Penelitian, Pendidikan dan Penerangan Ekonomi dan Sosial (LP3ES). Jakarta. p. 195-211.

Mubyarto \& Kartodirdjo, S. 1988. Pembangunan Pedesaan di Indonesia. Liberty Press. Yogyakarta. p. 105-112.

Nazir, M. 1983. Metode Penelitian. Ghalia Indonesia Jakarta. p.366-381.

Neisser, Uric. 1976. Cognition and Reality, Principles and Implication of Cognitive Psychology. San Francisco W.H. Freeman \& Co. p.78-104.

Sarjana, E. Reswati dan K. Susanto. 1994. Kelembagaan dan eksternalitas perusahaan inti rakyat sistem parsial dalam penangkapan cakalang di Sulawesi Tenggara. Jurnal Penelitian Perikanan Laut, No. 85. 1994. Balai Penelitian Perikanan Laut. Jakarta. p. 40-47.

Saleh, C. 1985. Kelayakan Teknologi Tanaman Pangan (Studi Kasus pada Proyek Bangun Desa Gunung Kidul). Pusat Penelitian Agro Ekonomi. Bogor. 42 pp.

Sax, G. 1982. Individual in Sociology: A Tex Book of Psychology, New York, Mc.Graw-Hill Book Co., p 45-57. dalam Azwar, S. 1988. Sikap Manusia, Teori dan Pengukurannya. Liberty. Jakarta. p. 268-315

Siegel, S. 1992. Statistik Non Parametrik Untuk IImu-IImu Sosial. Gramedia. Jakarta. p. 218-229 
Sinaga, R. 1985. Bahan-bahan Seminar Seperempat Abad UUPA. Universitas Indonesia. Jakarta. 29 pp.

Soehardjo dan Patong, D. 1987. Sendi-sendi Pokok Usaha Tani. Departemen Sosial Ekonomi, Fakultas Pertanian, IPB. Bogor. p. 36-41.

Thoha, M. 1993. Perilaku Organisasi. Rajawali Press. Jakarta. p.47-67.

Tornquist, O. 1990. Notes on the state rural change in Java and India, dalam Arif Budiman (eds.), State and Civil Society in Indonesia. Clayton, Victoria. Centre of Southeast Asia Studies. Monash University Press. p. 329-344
Walpole, R.E. 1993. Introduction to Statistics. Third Edition. Macmillan Publishing Co., In. New York. p. 325336.

White, B. dan Wiradi, G. 1989. Agrarian and Non Agrarian Bases of Inequality in Nine Javanese Villages, dalam Hart et al.(eds.), Agrarian Transformations: Local Processes and the State in The South-East Asia. Berkeley and Los Angeles. California Press. p.97-132. Zacharias, J.D. 1975. Lurah dan program pembangunan, dalam Cakrawala No. 4 Th. VII Lembaga Pengembangan Ilmu Sosial Universitas Kristen Satya Wacana. p.14-27 